\title{
The Implementation of Blended Learning Using Google Application in Mathematics Learning in the Pandemic Period
}

\author{
Nurul Kustiyati ${ }^{1}$, Dewi Nur Cahyaningsih² \\ bunda.nurul@smaasbsolo.sch.id1
}

\begin{abstract}
This study aims to enhance the learning innovation during the pandemic so that it can contribute to increasing students' activeness in mathematic learning even though the teacher and students rarely face to face. This study's design was classroom action research with four stages: planning, acting, observing, and reflecting. These stages were done in two cycles since the percentage of students' activeness in the second cycle has achieved the predetermined success indicator, which was $>80 \%$. Each cycle focused on the rule of sine and cosine materials. This study was conducted at Al Azhar Syifa Budi Solo Senior High School. In this study, the researcher acted as the subject of the class action, while the students of X MIPA Tahfidz as the subject of the class action recipient. The data analysis was carried out descriptively. Based on the observations before the action, the percentage of students' activeness was $45,8 \%$. In the first cycle, the activeness percentage improved $17 \%$, which was $62,8 \%$. In the second cycle, the percentage improved again to $83,34 \%$ (has achieved the success indicators). According to the result of this study, it could be concluded that the blended learning implementation by using google application could improve the students' activeness in mathematic learning during the pandemic.
\end{abstract}

Keywords: blended, learning, mathematic

Abstrak: $\quad$ Penelitian ini bertujuan menambah inovasi pembelajaran pada masa pandemi sehingga tetap dapat meningkatan keaktifan belajar matematika siswa meski guru dan siswa jarang bertatap muka. Penelitian ini adalah Penelitian Tindakan Kelas (PTK) dengan empat tahapan yaitu perencanaan, pelaksanaan, observasi, dan refleksi. Keempat tahapan tersebut dilaksanakan dalam dua siklus, karena pada siklus kedua persentase keaktifan siswa telah mencapai indikator keberhasilan yang telah ditetapkan sebelumnya yaitu $>80 \%$. Tiap siklus difokuskan pada materi aturan sinus cosinus. Penelitian ini dilaksanakan di SMA Al Azhar Syifa Budi Solo. Dalam penelitian ini, peneliti bertindak sebagai subjek pemberi tindakan kelas, sedangkan siswa kelas X MIPA Tahfidz sebagai subjek penerima tindakan. Analisis data dilakukan secara deskriptif. Dari hasil pengamatan sebelum tindakan diperoleh data persentase keaktifan sebesar 45,8\%. Pada siklus I persentase keaktifan meningkat menjadi 62,5\%. Pada siklus II meningkat lagi menjadi 83,34\% (telah mencapai indikator keberhasilan). Berdasarkan hasil penelitian tindakan kelas ini, dapat disimpulkan bahwa implementasi blended learning dengan google application dapat meningkatkan keaktifan belajar matematika di masa pandemi.

Kata Kunci: blended; learning; matematika

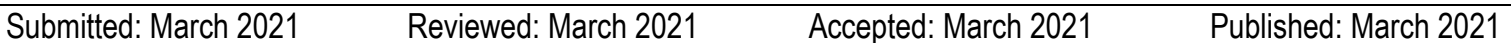


earning mathematics has become a necessity for the progress of someone in our complex society today. However, in reality, in learning mathematics, there are still many students who think that mathematics is a difficult and rarely desirable field of study. This student's view is a form of negative response that may be due to a lack of supporting aspects in mathematics learning, such as the provision of media and a boring form of learning, so students are not interested in learning mathematics. Student disinterest in learning mathematics leads to low student mathematics learning achievement. It often happens in most mathematics' subject matters in elementary, middle, and high school. Based on observations that have been conducted at SMA Al Azhar Syifa Budi Solo, the material of cosine sine rules showed that the students' learning activeness was low, indicated by the questionnaire that was filled out by students with very minimal scores. One of the factors that influence learning activeness is the learning model (Rahman, 2015). In general, teachers more often taught mathematics with direct learning models. In the normal era, it has not been considered sufficient to increase the learning mathematics activity; even more during a pandemic like this, of course, it still needs to be added to other learning models. The teacher also must understand what is needed by students (Zainuddin, 2015).

Along with the pandemic, learning has also been diverted online or e-learning because teachers and students did not have a schedule to carry out face-to-face learning at school. This situation made students less active in the learning process. Besides, teachers were still lacking in using effective and attractive learning models during this pandemic. In fact, teachers are the most crucial element in education and are demanded by professionals in delivering subject matter. One form of teacher professionalism in learning mathematics is that the teacher can package learning as appealing as possible.

The main weakness of e-learning is the meeting intensity between teachers and students, which is very minimal, and it is challenging to socialize between students (Wildavsky in Wena, 2014: 214). Thus, face-to-face learning is still essential to be applied, but, seeing the broad technological developments, teachers must also be able to use it to attract students to participate in the learning process. Therefore, one way to increase learning innovation during the pandemic so that it can still increase students' mathematics learning activeness is to apply a blended learning model by utilizing the google application in learning and assigning assignments for students. Blended learning is a learning model that combines face-to-face learning with e-learning. Blended learning has been transformed into a more measured and structured learning model, where students learn to master the material at home and come to class to discuss problem-solving (Zainuddin \& Halili, 2016). The researcher chose to use the google application because it was considered complete in the facilities provided, such as google meet, google sites, google form, google calendar, and others.

Blended learning is also a new concept in learning, where the delivery of material can be done in class and via online (Bielawski and Metcalf in Husamah, 2014). The combination is done well between face-to-face teaching, where teachers and students meet in person and through online media that can be accessed at any time. The combination of face-to-face learning with e-learning is due to limited time, quickly get bored students in the learning process, and the demands of increasingly broad technological developments.

The use of media technology in the 21st century has become a demand and need for every teacher to encourage students to learn independently, collaboratively, creatively, and critically in solving problems (Asfar and Zainuddin 2016). Blended learning is developed because of the weaknesses that appear in face-to-face learning and e-learning. Apart from being developed because of the emergence of the two lessons' weaknesses, blended learning was developed because of the advantages of face- 
to-face learning and e-learning. The advantages of blended learning expressed by Kusairi (in Husamah 2014: 35) are: a) Students are free to learn the subject matter independently by utilizing the material available online, b) Students can communicate/discuss with teachers or other students that do not have to be done in class (face to face), c) Learning activities carried out by students outside face-to-face hours can be managed and appropriately controlled by the teacher,, d) Teachers can add enrichment material through internet facilities, e) Teachers can ask students to read the material or take tests conducted before learning, f) Teachers can administer quizzes, provide feedback, and make effective use of test results, g) Students can share files with other students.

Based on Kusairi's explanation above, it can be concluded that the advantages of blended learning are that learning activities can be carried out in class or outside the classroom by utilizing technology to add to the subject matter, questions given in class or through online are managed and controlled in such a way by the teacher so that learning activities can take place, and communication among students and between teachers and students can be established both in class and outside the classroom (online) by forming a discussion group that takes advantage of technological developments in this era. Learning without communication will not produce results in accordance with the expectations of both teachers and students. Communication plays a vital role in the learning process and is key to creating an effective learning environment. (Dewey and Moore in Sari, 2016).

In the blended learning model, the teacher has plenty of time to provide feedback about student development outside of class hours and the opportunity to motivate students and answer unresolved questions in class (Zainuddin, 2017). Bawaneh (2011), in his research, stated that blended learning could improve students' understanding of accounting computation. Besides, Sria (2015), in her research, also affirmed that blended learning supports independent learning.

Based on the explanation above, blended learning is vital in filling learning during this pandemic so that it can become a learning innovation to increase students' activeness in learning mathematics.

\section{RESEARCH METHODS}

This study aimed to increase learning innovation during the pandemic so that it could still increase students' activeness in learning mathematics even though teachers and students rarely met face to face. This research was a Classroom Action Research (CAR). The research process was in the form of a cycle that lasted several times to achieve the desired goals. Suharsimi Arikunto (2013: 17) proposes that each cycle consists of four parts: 1) Planning. Planning is a step taken by the teacher when he will start his actions. 2) Acting. Acting is the implementation of the plans that have been made. 3) Observing, oservation is the process of observing the course of action, 4) Reflecting, reflection, or known as the event of contemplation, is a step to recall activities that have been carried out, namely when the action took place. What is very important to note by the researcher in Classroom Action Research (CAR) is that all students must be involved in this reflection. They were asked to recall events that occurred during the implementation of the action were asked whether they were happy or not, asked for opinions and suggestions for improvement in the next cycle.

This research was conducted through a collaborative work process between mathematics teachers and the researcher. The research was conducted at SMA Al Azhar Syifa Budi Solo. The researcher selected this place as a research place because the researcher is one of the mathematics teachers in this school. Besides, this school also had a representative number of students to study. This research was carried out from March 2020 to May 2020. In this study, the researcher acted as a teacher who gave action. Other mathematics teachers acted as observers of ongoing learning activities. Students of class X MIPA Tahfidz were as research subjects who received action. 
This research was a practical, situational, and conditional based on the problems that arose in the daily learning activities at the high school. The researcher was assisted by other mathematics teachers and always strived to obtain optimal learning outcomes through methods and procedures considered the most effective so that it was possible to have repeated actions with revisions, as necessary to increase mathematics learning activeness in the students of X MIPA Tahfidz class, SMA Al Azhar Syifa Budi Solo.

In early March, before the pandemic, learning was carried out face-to-face. In the second week of March, learning continued online. Learning was conducted using the Google application. It started from the teacher's preparation to make learning videos related to the material to be delivered, and then the teacher created a web or blog through google sites, where the link would be shared with students via google classroom. After that, the teacher prepared assignments for students online via a google form. Although all the materials and videos have been shared on the blog, the teacher still held regular meetings via google meet. At this meeting, the teacher could reflect with students and evaluate learning. To avoid students who did not join online learning, teachers had to pay extra attention to students, for example, by reminding students via WhatsApp before learning began. In this study, mathematics teachers and researchers would be involved in initial observation, planning, implementation, observation, reflection and discussion, evaluation and revision, and conclusion of the results. To obtain the material or information needed in the study, the researcher used the observation method and the test method (Mills, 2000). To conduct this research, a research instrument was also required in the form of validated observation sheets and test sheets. From the research data, it could be analyzed as follows: 1) Describing the research data for each cycle to compare with the data before the research was carried out by giving the initial test. The results of the test for all students were calculated as their class average. The results from cycle to cycle had to show an increase in student learning activeness and achievement. 2) Concluding the study results using the blended learning model by utilizing the google application in mathematics lessons on student learning activeness and achievement. This research is said to be successful if the percentage of student activeness in learning mathematics in X MIPA Tahfidz class, SMA Al Azhar Syifa Budi Solo, is > 80 .

\section{RESULTS AND DISCUSSION}

The implementation of classroom action research with the blended learning model using the google application was carried out in two cycles because, in cycle II, the indicators of success have been achieved. Each cycle consisted of four stages: planning, acting, observing, and reflecting. The main point of this research was the activeness of student learning, which included the activeness of students in paying attention to teacher explanations, the activeness of students in expressing opinions, the activeness of students in answering questions, the skills of students in solving questions, the courage of students in presenting portfolios, and the activeness of students in group work. Data analysis was performed descriptively. From the results of observations before the action, the percentage of activeness data obtained was $45.8 \%$. In the first cycle, the percentage of activeness increased to $62.5 \%$. In cycle II, researchers continued to make improvements in presenting learning so that, in this cycle, the percentage of activeness increased again to $83.34 \%$ (having reached the success indicator).

In cycle I implementation, students' activities in following the blended learning model using the google application have been running but have not been maximized. Students were still in the adaptation stage because the learning model used was different, which usually used a direct model, and now it employed an online learning model. In this first cycle, the teacher always provided opportunities for students to ask questions and express their opinions via google meet, but students were still afraid to ask questions and express their opinions even though they did not understand and were not clear about the material provided by the teacher. 
From the results of the study using a blended learning model by utilizing google application in the first cycle, where students' activeness was limited to student activity in paying attention to teacher explanations, student activeness in expressing opinions, student activeness in answering questions, student skills in solving problems, student courage in presenting portfolios, and the activeness of students in group work, the activeness data were obtained, which showed $62.5 \%$ of all indicators of students' activeness. Due to not achieving the desired indicators of success, the research action was continued in cycle II.

In cycle II implementation, student activities in group work began in accordance with the learning objectives, namely completing tasks where students worked together, exchanging ideas, and helping each other understand questions and find answers. The group work here was done online, where the teacher previously grouped the students. From the results of the study using the blended learning model by utilizing the google application in cycle II, where students' activeness was limited to student activeness in paying attention to teacher explanations, student activeness in expressing opinions, student activeness in answering questions, student skills in solving questions, students' courage in presenting portfolios, and the activeness of students in group work, the activeness data obtained showed $83.34 \%$ of all indicators of students' activeness.

From the observation sheet of student activeness in cycle II that has been filled by observers, it could be seen changes in student activity in cycle II. The criteria for assessing student activeness obtained were quite high, with the percentage of student activeness in the second cycle of $83.34 \%$. Because it has achieved the desired indicator of success, which was $>80 \%$ activeness, the observation of student activeness was only up to cycle II. Based on the results of research from cycle I and cycle II, it indicated that blended learning by utilizing google application could increase students' activeness in learning mathematics. It could be seen from the results of observations in cycle I, where the percentage of students' activeness was $62.5 \%$, and in cycle II, the percentage of student activeness increased to $83.34 \%$. It signified that in cycle II, the success indicator had been achieved. The results of observations of student activeness can be seen in table 1.

Table 1. Results of Student Activeness Observation

\begin{tabular}{llccc}
\hline & & \multicolumn{3}{c}{ Score } \\
\cline { 3 - 5 } No. & Observed Aspect & Pre-Cycle & Pre-Cycle 1 & Pre-Cycle 2 \\
& & & 3 & 4 \\
\hline 1. & Paying attention to the teacher's explanation & 2 & 2 & 3 \\
\hline 2. & Students' activeness in expressing opinions & 1 & 2 & 3 \\
\hline 3. & Students' activeness in answering questions & 2 & 2 & 3 \\
\hline 4. & Students' skills in solving questions & 2 & 3 & 3 \\
\hline 5. & Students' courage in presenting portfolios & 2 & 3 & 4 \\
\hline 6. & Students' activeness in group work & 2 & & \\
\hline
\end{tabular}

From the table of the percentage of student activity in learning, it can be seen that activeness could run thoroughly and evenly. Therefore, the results of these observations indicated an increase in students' activeness from cycle I to cycle II. Besides, the results of the evaluation analysis carried out in each cycle obtained an increase in achievement. It could be seen in the average score of students in each cycle, which has increased. The changes in the average score of students can be seen in Table 2, as follows: 
Table 2. Students' Average Score in Each Cycle

\begin{tabular}{lccc}
\hline Explanation & \multicolumn{3}{c}{ Cycle } \\
\cline { 2 - 4 } & Pre-Cycle & \multicolumn{1}{c}{ Cycle I } & Cycle II \\
\hline Total Score & 914 & 1055 & 1173 \\
\hline Average & 65,26 & 75,39 & 83,81 \\
\hline
\end{tabular}

In the teacher's activity observation sheet during the learning process, some changes could later be used as correction material. From the results of these observations, it can be presented in table 3 as follows:

Table 3. Percentage of observation for teachers in the learning process

\begin{tabular}{|c|c|c|}
\hline \multirow[t]{2}{*}{ Observed aspects } & \multicolumn{2}{|c|}{ The score of Each Cycle } \\
\hline & I & II \\
\hline $\begin{array}{l}\text { Stage 1: The teacher's ability to open lessons and } \\
\text { prepare initial conditions }\end{array}$ & 30 & 40 \\
\hline $\begin{array}{l}\text { Stage 2: The teacher's ability to deliver material } \\
\text { using blended learning by utilizing the google } \\
\text { application }\end{array}$ & 30 & 30 \\
\hline $\begin{array}{l}\text { Stage 3: Teacher's activeness in guiding students to } \\
\text { solve problems in groups }\end{array}$ & 30 & 30 \\
\hline $\begin{array}{l}\text { Stage 4: The suitability of the teacher in } \\
\text { implementing learning based on the lesson plan }\end{array}$ & 20 & 30 \\
\hline $\begin{array}{l}\text { Stage 5: The teacher's ability to help students reflect } \\
\text { on learning experiences }\end{array}$ & 20 & 30 \\
\hline Stage 6: The teacher's ability to close the lesson & 30 & 40 \\
\hline Total score & 160 & 200 \\
\hline Percentage & $66,67 \%$ & $83,34 \%$ \\
\hline
\end{tabular}

Based on the tables and graphs above, it can be seen that the students' activeness began to increase in cycle I, seen from the percentage of student activeness of $62.5 \%$ and the average on individual tests to 75.39. Meanwhile, the percentage of observations for teachers in cycle I was $66.67 \%$. Because in this cycle, the indicators of success have not been achieved, the researcher continued to cycle II.

In cycle II, students understood more about the blended learning model by utilizing the google application. It caused students to be more interested and active in learning mathematics. Students began to actively pay attention to teacher explanations, be active in expressing opinions, be active in answering questions, be active in solving questions, had the courage to present portfolios, and be active in group collaboration. In the second cycle, the percentage of student activeness was $83.34 \%$, and the average individual test score was 83.81. The percentage of observations for teachers was $83.34 \%$. In cycle II, the success indicator has been reached. The following is a display of the google application used in learning. 


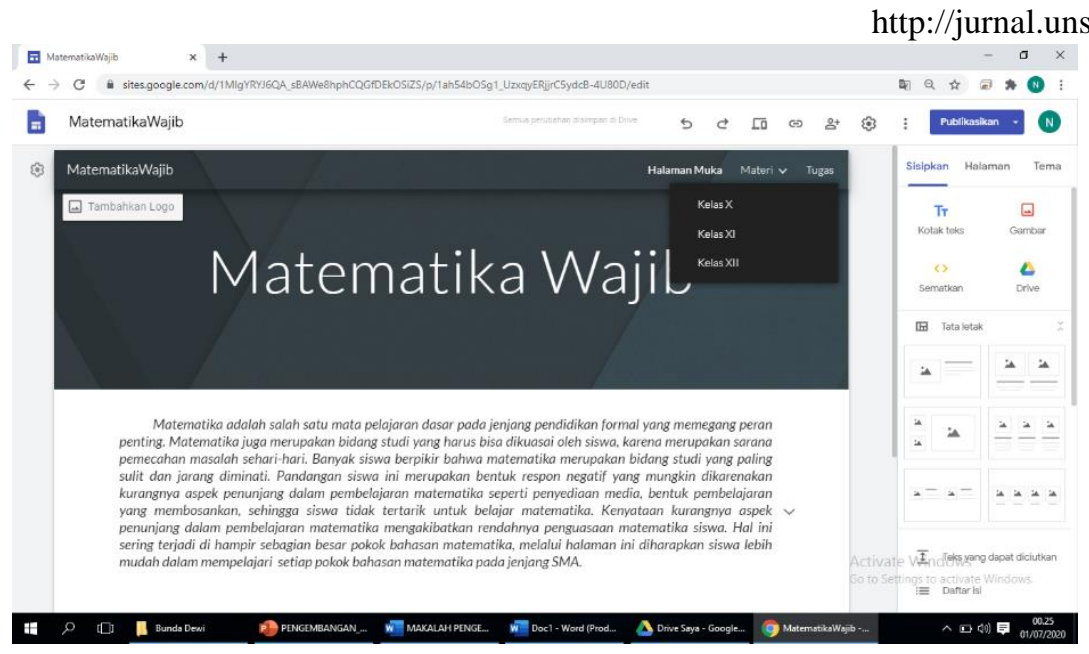

Figure 1. Google sites display

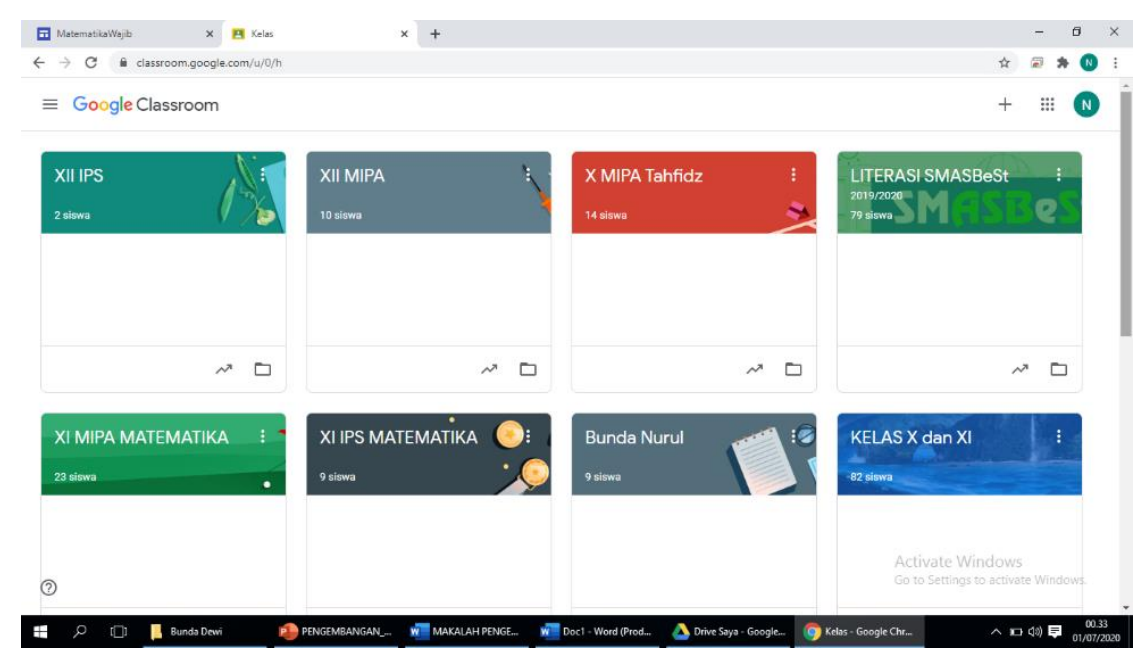

Figure 2. Gooogle Classroom Display

\section{CONCLUSIONS AND RECOMMENDATIONS}

Based on the research results that have been done, it was concluded that blended learning model by utilizing the google application could increase the activeness of learning mathematics in the material of the sine and cosines rules of X MIPA Tahfidz class, SMA Al Azhar Syifa Budi Solo in the 2019/2020 school year. The learning model with the blended learning method utilizing the Google application can be used by the teacher as another option besides the direct learning model on the material of the sine and cosine rules. Before using the blended learning model by utilizing the Google application, teachers should prepare teaching materials properly so that students can participate in learning effectively. Other researchers are expected to develop this research in a broader scope with similar studies or with more interesting learning models in other materials so that this research can be widely used.

\section{REFERENCES}

Asfar, N., \& Zainuddin, Z. (2016). Secondary students' perceptions of information, communication, and technology (ICT) use in promoting self-directed learning in Malaysia. The Online Journal of Distance Education and E-Learning, 3(4), 67-82.

Bawaneh, S. S. (2011). The Effects of Blended Learning Approach on Students' Performance: Evidence from a Computerized Accounting Course.International Journal of Humanities and Social Science. 1 (6), 63-69. 
Husamah. (2014). PEMBELAJARAN BAURAN (BLENDED LEARNING) Terampil Memadukan Keunggulan Pembelajaran Face-To-Face, E-learning Offline-Online dan Mobile Learning. Jakarta: Prestasi Pustaka.

Mills, G. E. (2000). Action Research: A Guide for the Teacher Researcher. Upper Saddle River, N J: PrenticeHall. Inc.

Rahman, B., Abdulrrahman, A., \& Rusmanto, N.E. (2015). Teacher-Based Scaffolding for Teachers' Professional Development in Indonesia. The Australian Journal of Teacher Education. 40 (11), 67-68.

Sari, Milya. (2016). Blended Learning, Model Pembelajaran Abad Ke-21 Di Perguruan Tinggi.Ta'dib, Jurnal Fakultas Pendidikan dan Pelatihan Guru, Universitas Batusangkar, 17(2), 126-136. Dari http://ecampus.iainbatusangkar.ac.id/ojs/index.php/takdib/article/view/267/264.

Sriarunrasme, J., Techataweewan, W., Mebusaya, R.P. (2015). Blended learning Supporting Self-Directed Learning and Communication Skills of Srinakharinwirot University's first year students. Journal Social and Behavior Science. 197(2015) 1564-1569.

Suharsimi Arikunto. (2013). Penelitian Tindakan Untuk Guru, Kepala Sekolah, dan Pengawas. Yogyakarta : Aditya Media.

Wena, Made. (2014). Strategi Pembelajaran Inovatif Kontemporer: Suatu Tinjauan Konseptual Operasional. Jakarta: Bumi Aksara.

Zainuddin, Z. (2015). Exploring the Potential of Blended learning and Learning Management Systems (LMS) for Higher Education in Aceh. English Journal, 2(2), 70-85.

Zainuddin, Z. (2017). First-Year College Students' Experiences in the EFL Flipped Classroom: A Case Study in Indonesia. International Journal of Instruction, 10(1), 133-150.

Zainuddin, Z., \& S. H. Halili. (2016). "Flipped Classroom Research and Trends from Different Fields of Study."The International Review of Research in Open and Distributed Learning IRRODL, 17(3), 313-340.

How to cite: Kutiyati, N. \& Cahyaningsih, D. N. (2021). The Implementation of Blended Learning Using Google Application in Mathematics Learning in the Pandemic Period. Teknodika, 19 (1), 82-89. DOI: https://doi.org/10.20961/teknodika.v19i1.49897 